\section{Efektivitas Penambahan Bahan Pengenyal yang Berbeda terhadap Kandungan Lemak dan Susut Masak Bakso Daging Ayam Broiler}

\author{
Nasrul \\ Intan Dwi Novieta \\ Irmayani
}

\begin{abstract}
Abstrak. Tujuan penelitian ini adalah untuk mengetahui pengaruh penambahan bahan pengenyal yang berbeda terhadap bakso daging ayam broiler. Hasil penelitian menunjukkan bahwa dengan penambahan bahan pengenyal yang berbeda yaitu Putih telur, Karagenan dan Agar-agar, memberikan pengaruh yang sangat nyata. Rata-rata nilai kandungan Lemak tertinggi ke terendah yaitu T3 sebesar $(0,71)$, T1 sebesar $(0,64), T 2$ sebesar $(0,61)$, dan T0 sebesar $(0,51)$. Rata-rata nilai Susut Masak tertinggi ke terendah yaitu T0 sebesar $(31,15)$, T1 sebesar $(20,82)$, T2 sebesar $(16,77)$, dan T3 sebesar (2,35). Dari hasil penelitian maka diketahui bahwa perlakuan terbaik yang dapat direkomendasikan yaitu perlakuan T0 untuk kandungan Lemak dan perlakuan T3 untuk Susut Masak.

Kata Kunci: Kandungan Lemak, Susut masak, Karagenan, Putih Telur dan Agar-agar.
\end{abstract}

\section{Pendahuluan}

Daging ayam merupakan pilihan masyarakat untuk memenuhi kebutuhan protein hewani. Daging ayam banyak dipilih karena harganya lebih murah dibandingkan jenis daging lainnya dan sesuai dengan selera masyarakat. Salah satu jenis ayam yang permintaan dagingnya cukup banyak adalah daging ayam broiler. Peranan daging ayam broiler di Indonesia sangat penting untuk memenuhi kebutuhan daging ayam broiler dimasyarakat. Hingga saat ini pun usaha ayam broiler tersebut tetap berprospek dan permintaan daging broiler terus meningkat. Seiring dengan meningkatnya produksi daging ayam broiler untuk memenuhi kebutuhan konsumen, terjadi pula peningkatan kesadaran masyarakat tentang kesehatan pangan. Saat ini masyarakat menyadari bahwa daging ayam broiler yang dikonsumsi harus aman, utuh, sehat, dan halal. Hal ini juga menjadi tantangan dan problema yang dihadapi oleh pedagang ayam. Pedagang tidak ingin menjual daging ayam broiler dengan waktu yang panjang dikarenakan produk ayam broiler mudah busuk (perishable). Hal ini disebabkan adanya mikroorganisme di dalam daging tersebut yang menyebabkan terjadinya pembusukan daging yang berlangsung cepat apabila tidak ditangani secara langsung. Daging sering diolah untuk meningkatkan nilai ekonomis, masa simpan dan selera konsumsi masyarakat melalui penganekaragaman produk seperti dendeng, abon, sosis dan bakso. Bakso adalah produk daging yang banyak dikonsumsi dan merupakan

\section{BIONATURE}

p-ISSN 1411 - 4720

e-ISSN 2654 - 5160

Abstract. The purpose of this study was to determine the effect of addition of chewing agents which differed on broiler chicken meatballs. The results of study show that with the addition of different ingredients that are egg white, carrageenan and gelatin have a very real effect. The average value of the highness fat content at the lowest is T3 at $(0,71)$ T1 at $(0,64)$ T2 at $(0,61)$ and $T 0$ at $(0,51)$. The highest average cooking shrinkage value is T0 of $(31,15) T 1$ of $(20,82) T 2$ of $(16,77)$ and $T 3$ of $(2,35)$. From the results of this study, it is known recommended is $T 0$ treatment for fat content and T3 treatment for cooking losses.

Keywords: Fat content, Cooking shrinkage, Egg white, Carrageenan, and Gelatin

Nasrul

Universitas Muhammadiyah Parepare Indonesia

Intan Dwi Novieta

Universitas Muhammadiyah Parepare Indonesia

Irmayani

Universitas Muhammadiyah Parepare Indonesia 
bahan pangan yang sangat populer di kalangan masyarakat, sehingga konsumsi protein hewani melalui produk ini dapat meningkatan gizi masyarakat. Bakso yang dijumpai di pasar dan supermarket dibuat dari berbagai jenis daging, antara lain daging sapi, ayam dan ikan.

Daging ayam broiler banyak digunakan dalam pembuatan bakso karena daging ayam broiler mempunyai kelebihan, antara lain termasuk daging putih, lebih disukai, harganya relatif murah, mempunyai kandungan kolesterol yang rendah, lebih empuk dan berkembang baik, lembut, halus, tulang dada lentur, mempunyai marbling yang cukup dan jaringan lemak yang minimal. Daging ayam broiler bagian dada tanpa kulit per $100 \mathrm{~g}$ mengandung 74,2 g air, 24,0 g protein dan 1,1 g lemak (Holland et al. (1997).

Pada proses pengolahan bakso sering ditambahkan Bahan Tambahan Makanan (BTM) tertentu, antara lain karagenan, putih telur (albumen), agar-agar dan soda kue (NaHCO3) yang berfungsi sebagai bahan pengenyal. Putih telur merupakan bahan pengenyal yang alami, sedangkan soda kue merupakan bahan pengenyal sintetis yang diizinkan. Putih telur (albumen) mengandung jumlah protein yang tinggi dan kalau dipanaskan akan menggumpal, membentuk gel dan mengkompakkan daging (Thenawidjaja dkk., 1999). Soda kue bila dipanaskan, asamnya akan bereaksi dan membentuk garam, air dan gas yang akan menyebabkan mengembangnya bahan (Anonim, 2003).

Selain bahan pengenyal alami dan sintetis yang dizinkan tersebut, ada juga produsen bakso yang masih menggunakan bahan pengenyal yang dilarang seperti boraks. Hal ini dilakukan oleh produsen untuk mengejar keuntungan yang lebih besar, karena bahan tersebut sangat murah dan mudah didapat, padahal bahan tersebut sangat berbahaya bagi kesehatan manusia. Boraks merupakan kristal putih yang lunak, bila ditambahkan dalam produk daging akan menghasilkan produk yang kesat dan kenyal teksturnya.

Oleh karena itu dibutuhkan bahan pengenyal alami dalam proses pembuatan bakso. Bahan pengenyal alami yang dapat digunakan adalah putih telur, keragenan, dan agar-agar. Berdasarkan hal di atas, maka dilakukan penelitian yang berjudul Kandungan Lemak dan Susut Masak Bakso Daging Ayam Broiler Pada Penambahan Bahan Pengenyal yang Berbeda.

\section{Metode Penelitian}

\section{Waktu dan Tempat Penelitian}

Penelitian ini akan dilaksanakan pada bulan Juli 2018 di laboratorium Teknologi Pengolahan. Hasil Ternak Fakultas Pertanian Peternakan dan Perikanan Universitas Muhammadiyah Parepare dan dilanjutkan Analisis Kadar Lemak di Laboratorium Kimia Makanan Ternak Fakultas Peternakan Universitas Hasanuddin Makassar.

\section{Alat dan Bahan}

Adapun alat yang digunakan dalam penelitian ini adalah pisau, blender, panci, kompor, sendok, baskom dan lain-lain

Bahan yang akan digunakan dalam penelitian ini adalah daging ayam broiler, agar-agar, putih telur, karagenan, merica, garam, bawang putih, tepung tapioka, air dan es batu.

Rancangan percobaan yang digunakan dalam penelitian ini adalah Rancangan Acak Lengkap (RAL) dengan 4 perlakuan dan 3 ulangan. Perlakuan yang diterapkan adalah:

T0 = Bakso ayam tanpa penambahan pengenyal (kontrol)

$\mathrm{T} 1=$ Penambahan Putih Telur 1 butir/kg sebagai bahan pengenyal

T2 = Penambahan Karagenan 10-gram sebagai bahan pengenyal

T3 = Penambahan Agar-agar 7-gram sebagai bahan pengenyal 
Data yang diperoleh dari panelitian ini akan dihitung dengan menggunakan Rancangan Acak Lengkap (RAL) menurut Gazpersz (1991) dengan bantuan program SPSS Versi 16.0 For Windows.

\section{Hasil dan Pembahasan}

\section{Kadar Lemak}

Hasil analisis kadar lemak (\%) bakso dengan penambahan bahan pengenyal yang berbeda dapat dilihat pada tabel 1 .

Tabel 1. Nilai Kadar Lemak Bakso dengan Penambahan Bahan Pengenyal yang Berbeda

\begin{tabular}{|c|c|c|c|c|}
\hline Perlakuan & & Ulangan (U) & & Rata-rata \\
\hline (T) & U1 & U2 & U3 & $0,51^{\mathrm{a}}$ \\
\hline $\begin{array}{c}\text { T0 } \\
\text { (Kontrol) }\end{array}$ & 0,51 & 0,49 & 0,54 & $0,64^{\mathrm{ab}}$ \\
\hline $\begin{array}{c}\text { T1 } \\
\text { (Putih Telur) }\end{array}$ & 0,62 & 0,76 & 0,56 & $0,61^{\mathrm{ab}}$ \\
\hline $\begin{array}{c}\text { T2 } \\
\text { (Karagenan) }\end{array}$ & 0,67 & 0,60 & 0,57 & $0,71^{\mathrm{b}}$ \\
\hline $\begin{array}{c}\text { T3 } \\
\text { (Agar-agar) }\end{array}$ & 0,66 & 0,73 & 0,76 & \\
\hline
\end{tabular}

Keterangan: Superkrip yang sama pada kolom yang sama menunjukkan tidak berpengaruh nyata $(\mathrm{P}>0,05)$.

Adapun nilai rata-rata dari setiap perlakuan yaitu T0 $(0,51)$, T1 $(0,64), \mathrm{T} 2(0,61)$ dan T3 $(0,71)$ dan disajikan dalam diagram batang berikut.

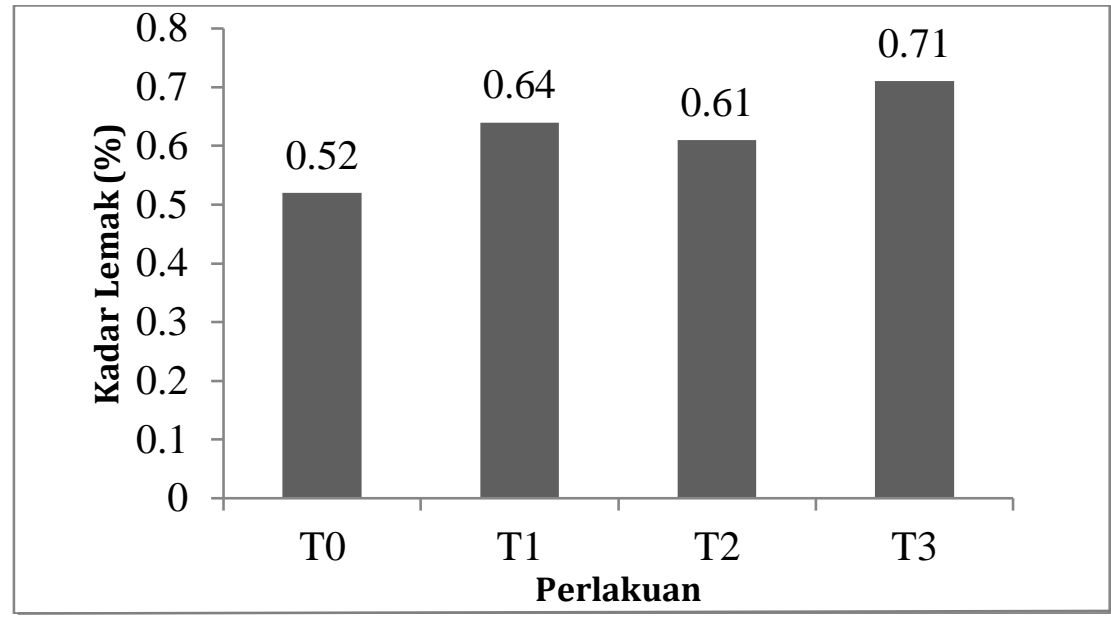

\section{Gambar 1. Nilai Rata-Rata dari Setiap Perlakuan}

Berdasarkan analisis ragam diketahui bahwa perlakuan bahan pengenyal yang berbeda tidak berpengaruh nyata $(\mathrm{P}>0,05)$ terhadap kandungan lemak kasar. Tetapi setelah dilanjutkan uji Duncan terdapat perbedaan yang nyata anatara perlakuan T0 dengan T3 tetapi tidak berbeda nyata dengan perlakuan T2 dan T1.

Hasil analisis ragam menunjukkan bahwa perlakuan penambahan bahan pengenyal yang berbeda tidak berpengaruh nyata $(\mathrm{P}>0,05)$ terhadap bakso. Pada hasil analisis Duncan terdapat perbedaan nyata dimana $\mathrm{T} 0$ berbeda nyata dengan $\mathrm{T} 3$ tetapi tidak berbeda nyata 
dengan T2 dan T1. Adapun hasil yang terbaik adalah kadar lemak yang memiliki nilai terendah yaitu pada perlakuan T0 (Kontrol) tanpa pengenyal dengan nilai rata-rata 0,51 dibandingkan dengan perlakuan yang lain yang masing-masing memiliki nilai rata-rata T1 $(0,64), \mathrm{T} 2(0,61)$ dan T3 $(0,71)$.

Penambahan bahan pengenyal dapat meningkatkan kadar lemak bakso daging ayam broiler. Karena semakin banyak penambahan rumput laut, kadar lemak semakin meningkat walaupun tidak terlalu banyak. Keadaan ini bisa berasal dari kandungan lemak rumput laut. Seperti yang diketahui bahan pengenyal misalnya karagenan dan agar-agar terbuat dari rumput laut.

Selain itu putih telur juga mempengaruhi kadar lemak bakso. Semakin meningkat penambahan putih telur, kadar lemak produk meningkat. Hal ini disebabkan kemampuan pengikatan lemak oleh porsi molekul hidrofobik yang dimiliki lesitin pada telur. Protein tersebut memiliki kemampuan dalam penyerapan minyak (De Man, 1997).

\section{Susut Masak}

Hasil analisis susut masak (\%) bakso dengan penambahan bahan pengenyal yang berbeda dapat dilihat pada tabel 2 .

Tabel 2. Nilai Susut Masak (\%) Bakso dengan Penambahan Bahan Pengenyal yang Berbeda.

\begin{tabular}{|c|c|c|c|c|}
\hline Perlakuan & & Ulangan (U) & & Rata-rata \\
\hline $\begin{array}{c}\text { (T) } \\
\text { T0 } \\
\text { (Kontrol) }\end{array}$ & 29,34 & 31,52 & 32,60 & $31.15^{\mathrm{a}}$ \\
\hline $\begin{array}{c}\text { T1 } \\
\text { (Putih Telur) }\end{array}$ & 21,73 & 18,47 & 22,28 & $20,82^{\mathrm{b}}$ \\
\hline $\begin{array}{c}\text { T2 } \\
\text { (Karagenan) }\end{array}$ & 17,39 & 17,71 & 15,21 & $16,77^{\mathrm{c}}$ \\
\hline $\begin{array}{c}\text { T3 } \\
\text { (Agar-agar) }\end{array}$ & 4,34 & 2,17 & 0,54 & $2,35^{\mathrm{d}}$ \\
\hline
\end{tabular}

Keterangan: Superkrip yang berbeda pada kolom yang sama menunjukkan berpengaruh sangat nyata $(\mathrm{P}<0,01)$.

Adapun nilai rata-rata dari setiap perlakuan yaitu T0 $(31,15), \mathrm{T} 1(20,28), \mathrm{T} 2(16,77)$ dan T3 $(2,35)$ dan disajikan dalam diagram batang berikut.

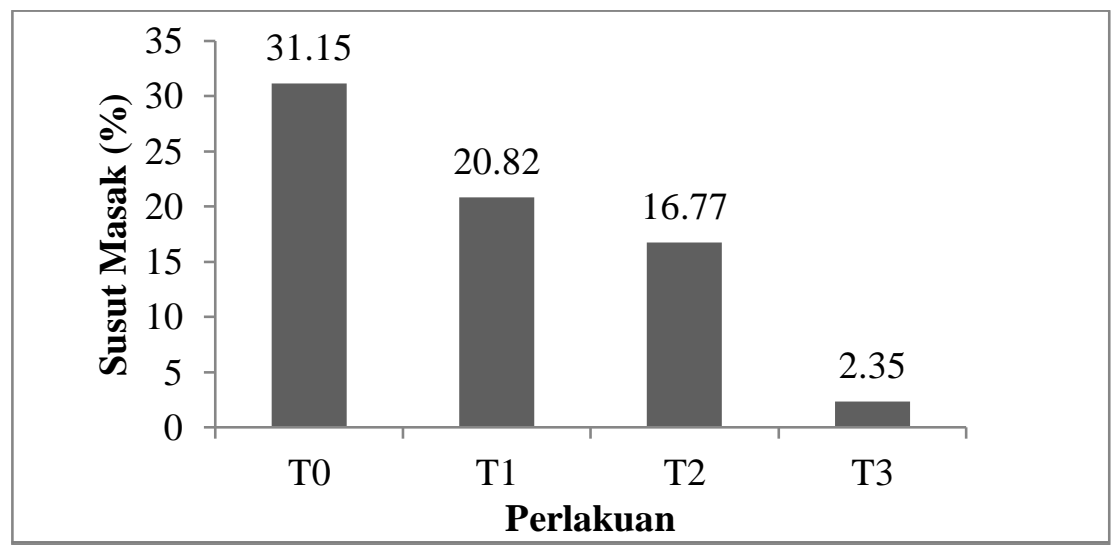

Gambar 2. Nilai Rata-Rata dari Setiap Perlakuan 
Berdasarkan analisis ragam diketahui bahwa penambahan bahan pengenyal yang berbeda berpengaruh sangat nyata $(\mathrm{P}<0,01)$ terhadap bakso.

Hasil analisis ragam menunjukkan bahwa perlakuan penambahan bahan pengenyal yang berbeda berpengaruh sangat nyata $(\mathrm{P}<0,01)$ terhadap bakso. Dari hasil analisis Duncan terdapat perbedaan yang sangat nyata dimana T0 berbeda sangat nyata dengan T1, T2 dan T3. $\mathrm{T} 1$ berbeda sangat nyata dengan $\mathrm{T} 0, \mathrm{~T} 2$ dan $\mathrm{T} 3$. T2 berbeda sangat nyata dengan $\mathrm{T} 0, \mathrm{~T} 1$ dan $\mathrm{T} 3$. Serta T3 berbeda sangat nyata dengan T0, T1 dan T2. Dari hasil analisis bahan, diperoleh hasil yang terbaik yaitu pada perlakuan T3 dengan penambahan bahan pengenyal agar-agar dengan nilai rata-rata $2,35 \%$ karena memiliki nilai susut masak terendah. Hal ini sesuai dengan pendapat Soeparno (2009) bahwa semakin kecil nilai susut masak maka semakin baik kualitasnya baik dari rasa maupun organoleptiknya termasuk nilai ekonomisnya.

Winarno (1997) menambahkan bahwa produk daging olahan sebaiknya mengalami susut masak sedikit mungkin karena susut masak mempunyai hubungan erat dengan rasa maupun organoleptiknya. Soeparno (2009) menyatakan hal sama bahwa daging bersusut masak rendah mempunyai kualitas yang relatif baik dibandingkan dengan daging bersusut masak besar, karena resiko kehilangan nutrisi selama pemasakan akan lebih sedikit. Di dalam agar-agar terdapat zat yang dapat membentuk polisakarida (serat) dan dapat memerangkap molekul air sehingga terbentuk koloid gel yang menyebabkan daya ikat air tinggi. Susut masak merupakan indikator nilai nutrisi daging yang berhubungan dengan kadar air daging, yaitu banyaknya air yang terikat didalam dan di antara otot. Daya ikat air (WHC) yang rendah akan mengakibatkan nilai susut masak yang tinggi.

Besarnya susut masak juga dipengaruhi oleh $\mathrm{pH}$, panjang sarkomer serabut otot, panjang potongan serabut otot, status kontraksi myofibril, ukuran dan berat sampel daging serta penampang melintang daging ayam (Soeparno, 2009). Daging yang mempunyai pH lebih rendah akan menghasilkan nilai susut masak yang lebih tinggi, karena semakin rendah $\mathrm{pH}$ maka daya mengikat air daging akan semakin rendah, sehingga banyak air yang keluar (Sudarman, 2008).

\section{Kesimpulan}

Berdasarkan hasil pengamatan dan pembahasan maka dapat diambil kesimpulan bahwa penambahan bahan pengenyal yang berbeda tidak berpengaruh nyata $(P>0,05)$ terhadap bakso. Adapun hasil yang terbaik adalah kadar lemak yang memiliki nilai terendah yaitu pada perlakuan T0 (Kontrol) tanpa pengenyal.

Perlakuan penambahan bahan pengenyal yang berbeda berpengaruh sangat nyata $(\mathrm{P}<0,01)$ terhadap bakso. Dari hasil analisis bahan, diperoleh hasil yang terbaik yaitu pada perlakuan T3 dengan penambahan bahan pengenyal agar-agar karena memiliki nilai susut masak terendah.

\section{Referensi}

Anonim. 2003). Tea and Health dalam www.jaxtea.com/abouttea/tea consumption.htm. diakses pada tanggal 28 Mei 2018.

Gasperz, Vincent. (2007). Lean six sigma for manufacturing and service Industries, Jakarta. PT. Gramedia Pustaka Utama. Diakses tanggal 28 Mei 2018.

De Man, J.M. (1997). Kimia Makanan. Institut Teknologi Bandung, Bandung. Diakses tanggal 16 Agustus 2018. 
Holland, A., A.A. Welch, I.D. Unwin, D.H. Buss, A.A. Paul, \& D.A.T. Southgate. (1997). The Compostion of Foods. Fifth Revised and Extended Edition. The Royal Society of Chemistry and Ministry of Agriculture, Fisheries and Food. Diakses tanggal 28 Mei 2018.

Soeparno. (2009). Ilmu dan Teknologi Daging. Gadjah Mada University Press. Yogyakarta. (6), 152-156, 289-290, 297-299. Diakses tanggal 16 Agustus 2018.

Sudarman., A. (2008). Penambahan Sabun-kalsium dari Minyak Ikan Lemuru dalam RansumPengaruhnya terhadap Sifat Kimia dan Fisik Daging Domba. Departemen Ilmu Nutrisi dan Teknologi Pakan, Fakultas Peternakan IPB. Bogor. Diakses tanggal 16 Agustus 2018.

Thenawidjaja. (1987) Bahan Tambahan Makanan. http://library. Usu. ac.id/download/fkm/fkm-albiner.pdf. Fakultas Kesehatan Masyarakat, USU. Diakses tanggal 28 Juli 2018.

Winarno, F.G. (1997). Kimia Pangan dan Gizi. PT. Gedia. Jakarta. Di Akses pada tanggal 28 Mei 2018.

\begin{tabular}{|c|c|}
\hline Nasrul & $\begin{array}{l}\text { Program Studi Peternakan, Fakultas Pertanian, Peternakan dan } \\
\text { Perikanan. Universitas Muhammadiyah Parepare. } \\
\text { E-mail: } \underline{\text { nasrunaccu@gmail.com }}\end{array}$ \\
\hline Intan Dwi Novieta & $\begin{array}{l}\text { Program Studi Peternakan, Fakultas Pertanian, Peternakan dan } \\
\text { Perikanan. Universitas Muhammadiyah Parepare. } \\
\text { E-mail: nasrunaccu@gmail.com }\end{array}$ \\
\hline Irmayani & $\begin{array}{l}\text { Program Studi Peternakan, Fakultas Pertanian, Peternakan dan } \\
\text { Perikanan. Universitas Muhammadiyah Parepare. } \\
\text { E-mail: nasrunaccu@gmail.com }\end{array}$ \\
\hline
\end{tabular}

